\title{
ГРАЖДАНСКОЕ ПРАВО
}

\author{
CIVIL LAW
}

DOI: $10.22363 / 2313-2337-2021-25-2-541-561$

Научная статья

\section{Смежные права: концептуальные подходы, определение и основные характеристики}

\author{
Н.В. Бузова \\ Российский государственный университет правосудия, \\ 2. Москва, Российская Федераиия, \\ nbuzova@yandex.ru
}

\begin{abstract}
Аннотация. Развитие технологий способствует появлению новых нематериальных объектов, имеющих потенциальную ценность и направленность на распространение результатов творчества и информации. В этой связи общество заинтересовано в поощрении деятельности субъектов, создающих такие объекты. Одним из вариантов охраны таких объектов является предоставление создателям или организаторам смежных прав. Учитывая технологические изменения в обществе, связанные с использованием информационно-телекоммуникационных сетей, искусственного интеллекта, вопросы предоставления смежных прав новым субъектам становятся актуальными. С целью выявления возможности расширения института смежных прав и определения направлений такого расширения в статье анализируются основные подходы формирования института смежных прав, их характеристики и делается попытка представить рабочее определение понятия смежных прав. На основе сравнительного анализа рассматриваются российские и зарубежные законодательные акты в сфере интеллектуальной собственности, международные договоры по авторскому праву и смежным правам, а также правовая литература. Наиболее поддерживаемой идей формирования института смежных прав представляется функциональное назначение деятельности субъектов смежных прав, выступающих посредниками между авторами и представителями общественности. Однако сам институт трансформируется, и признание смежных прав за новыми субъектами зависит уже не только от функционального назначения деятельности, но и от их организационного или экономического вклада, направленного на обработку и распространение произведений и информации. Можно предположить, что институт смежных прав продолжит расширяться по мере развития технологий и востребованности у общественности новых услуг, оказываемых благодаря новым технологиям.
\end{abstract}

Ключевые слова: авторское право, изготовитель фонограммы, интеллектуальная собственность, исключительное право, исполнитель, смежные права, организация вещания

Конфликт интересов: Автор заявляет об отсутствии конфликта интересов.

(С) Бузова Н.В., 2021

This work is licensed under a Creative Commons Attribution 4.0 International License https://creativecommons.org/licenses/by/4.0 
Дата поступления в редакиию: 22 июля 2020 г.

Дата принятия к печати: 15 апреля 2021 г.

\title{
Для цитирования:
}

Бузова Н.В. Смежные права: концептуальные подходы, определение и основные характеристики // RUDN Journal of Law. 2021. T. 25. № 2. С. 541-561. DOI: 10.22363/23132337-2021-25-2-541-561

DOI: $10.22363 / 2313-2337-2021-25-2-541-561$

Research Article

\section{Related rights: conceptual approaches, definition and key features}

\author{
Natalia V. Buzova \\ Russian State University of Justice, \\ Moscow, Russian Federation, \\ nbuzova@yandex.ru
}

\begin{abstract}
The development of technologies contributes to the emergence of new intangible objects that have potential value and are aimed at spreading the results of creativity and information. In this regard, the society is interested in encouraging the activities of entities that create such objects. One of the options for the protection of such objects is to grant the related rights. Considering the technological changes in society associated with the use of information and telecommunication networks and artificial intelligence, the issues of granting related rights to new entities gain relevance. In order to identify the possibility of expanding the institution of related rights and determine the directions of such expansion, the article analyzes the main approaches to the formation of the institute of related rights, their characteristics, and attempts to deliver a working definition of the concept of related rights. On the basis of a comparative analysis, the author considers Russian and foreign legislative acts in the field of intellectual property, international treaties on copyright and related rights, as well as legal literature. The most supported idea of the formation of the institute of related rights is the functional purpose of the activities of subjects of related rights, acting as intermediaries between authors and representatives of the public. However, the institute itself is evolving and recognition of related rights for new subjects depends not only on the functional purpose of the activity, but also on their organizational and/or economic contribution aimed at processing and disseminating works and information. It can be assumed that the institute of related rights will continue to expand with the development of technologies and the public demand for new services provided by new technologies.
\end{abstract}

Key words: copyright, intellectual property, producer of phonogram, exclusive rights, performer, related rights, broadcasting organization

Conflicts of interest. The author declared no conflicts of interest.

Article received 22nd July 2020

Article accepted 15th April 2021 


\section{For citation:}

Buzova, N.V. (2021) Related rights: conceptual approaches, definition and key features. RUDN Journal of Law. 25 (2), 541-561. (in Russian). DOI: 10.22363/2313-2337-2021-252-541-561

\section{Введение}

Несмотря на то, что изучением правовой природы авторского права занимаются на протяжении многих столетий ученые во всем мире, всеохватывающего определения понятия «авторское право» до настоящего времени не найдено. При этом существует множество концепций (теорий) возникновения и реализации этой правовой категории, которые пытаются обосновать не только причину его возникновения, но и выявить наиболее существенные его характеристики.

Институт смежных прав по сравнению с авторским правом не имеет такого продолжительного применения, для того чтобы успели сформироваться научнообоснованные концепции. Вместе с тем специалисты пытаются установить общие концептуальные подходы, которые могли бы лечь в основу формирования института смежных прав. На теоретическую необоснованность понятия «смежные права» указывает, в частности, Д. Липцик (Lipszyc, 2002:302). Представляется, что создание определения понятия «смежные права», также как и выявление общих характеристик и формирование концептуальных подходов, не является самоцелью. Изучение первопричин и установление общих характеристик необходимо для составления прогнозов, определения тенденций развития такого института, возможности его расширения посредством дополнения правами на иные объекты, установления пределов осуществления прав. Кроме того, это имеет значение и для правоприменения, в том числе защиты прав в судебном порядке, поскольку такая информация может содействовать подтверждению наличия (существования) соответствующих прав у правообладателя и применению наиболее эффективных способов защиты таких прав. В этой связи, прежде чем рассматривать понятие «смежные права» и их характеристики, целесообразно остановиться на основных концептуальных подходах формирования института смежных прав, которые позволят выявить общие элементы, лежащие в его основе. Для выявления общих характеристик, относящихся к смежным правам, в настоящей статье будут рассмотрены положения международных договоров и информационных материалов по авторскому праву и смежным правам, а также будет проведен сравнительный анализ законодательных актов Российской Федерации и европейских государств, где институт смежных прав наиболее развит.

\section{Основные концептуальные подходы формирования института смежных прав}

Если проанализировать законодательные акты большинства государств, в которых признаются права на интеллектуальную собственность, то при таком 
глобальном охвате можно условно говорить о «субъектном» подходе возникновения и функционирования института смежных прав, при котором права предоставляются определенной группе субъектов.

М. Фичор различает смежные права в традиционном узком смысле и в широком смысле, относя к первой категории «права исполнителей в отношении их исполнений, права производителей фонограмм в отношении их фонограмм и права организаций эфирного вещания в отношении их передач эфирного вещания» (Ficsor ed., 2004:310). Данный подход к понятию «смежные права» использован в публикациях Всемирной организации интеллектуальной собственности (далее - ВОИС), например, в Глоссарии ВОИС по авторскому праву и смежным правам ${ }^{1}$, его можно обнаружить и в юридической литературе советского периода (Kuznetsov, 1986:47), в которой анализируются международные конвенции и зарубежное законодательство в области авторского права. Представляется, что такой подход основывается на положениях Международной конвенции об охране прав исполнителей, изготовителей фонограмм и вещательных организаций (Рим, 26 октября 1961 г., далее - Римская конвенция). И именно права указанных лиц относят в большинстве стран мира к смежным правам. Несмотря на то, что в Римской конвенции не упоминается понятие «смежные права», специалисты рассматривают ее именно как конвенцию по смежным правам в противовес Бернской конвенции об охране литературных и художественных произведений (Берн, 9 сентября 1886 г.), посвященной авторским правам на произведения. Вторая категория с широким пониманием данного термина, по мнению М. Фичора, охватывает помимо прав перечисленных выше субъектов также права издателей на типографское оформление их опубликованных изданий и специальные права на базы данных (Ficsor ed., 2004:310). Представляется, что подход, предлагаемый М. Фичором, не раскрывает сущности, правовой природы смежных прав, а только указывает, права каких лиц могут относиться к смежным правам. Говоря о широком понимании, вернее было бы сказать, что к категории смежных прав относятся права и других субъектов, так как перечень субъектов смежных прав, как будет отмечено ниже, достаточно широк и не ограничивается перечисленными М. Фичором лицами.

То есть согласно «субъектному» подходу права определенных в национальном законе или международном договоре лиц (субъектов) признаются смежными. Однако у такого подхода имеется существенный недостаток. В странах англо-американской системы смежные права в отношении результатов интеллектуальной деятельности приведенных выше субъектов не предусмотрены, и соответствующие результаты охраняются в режиме авторского права ${ }^{2}$ или специальным законодательством.

Вместе с тем в информационных источниках ${ }^{3}$ Соединенного Королевства термин «смежные права» используется применительно к результатам

\footnotetext{
${ }^{1}$ WIPO Glossary of terms of the law of copyright and neighboring rights (1980). WIPO Publication № 816. Geneva. Switzerland. P. 167.

${ }^{2}$ Например, звукозаписи и передачи организаций эфирного вещания в Соединенном Королевстве.

${ }^{3}$ Например, Copyright and related rights. The National Archives. 2013. Available at: https//nationalarchives.gov.uk. [Accessed 25 ${ }^{\text {th }}$ July 2020].
} 
интеллектуальной деятельности в отношении моральных прав (близких по своей природе к личным неимущественным правам, признаваемым в государствах континентального права в отношении результатов интеллектуальной деятельности) и специального права на базу данных. То есть категорией «смежные права» (related rights) охватываются те права, которые не подпадают под категорию «авторское право» (copyright), представляющее собой имущественное право (property right), признаваемое в отношении определенной группы произведений.

Моральные права и специальное право на базы данных, предусмотренные Законом Соединенного Королевства об авторском праве, патентах и промышленных образцах 1988 г. ${ }^{4}$ (далее - Закон Соединенного Королевства), по своей правовой природе существенным образом отличаются от авторского права (copyright). Но согласно законодательству Соединенного Королевства при осуществлении авторских прав (copyright) и смежных прав сохраняется связь, поскольку указанные категории прав признаются в отношении одних и тех же объектов. Положения, касающиеся указанных прав, нашли отражение в законодательстве Соединенного Королевства в результате его реформирования, вызванного в том числе присоединением к Парижскому акту Бернской конвенции, к Договору ВОИС по исполнениям и фонограммам, а также участием Соединенного Королевства в Европейском Союзе, в рамках которого приняты ряд директив, касающихся смежных прав. Следует отметить, что положения о правах исполнителей были отражены в законодательстве Соединенного Королевства в более ранний период 5 и вошли отдельной частью II в Закон Соединенного Королевства. Однако соответствующий раздел закона не был назван «смежное право» или «смежные права». При этом в юридической литературе (Dworkin \& Taylor, 1989), в которой анализируется законодательство об авторском праве Соединенного Королевства, отдельные авторы относят к смежным правам права исполнителей.

Некоторые специалисты, например, А.Г. Матвеев, в части оснований для формирования самостоятельного института смежных прав выделяют также «объектный», «юридико-технический» и «функциональный» подходы (Matveev, 2019a: 54-60).

Если проанализировать положения Федерального закона Австрии от 9 апреля 1936 г. «Об авторском праве на произведения литературы и искусства и о смежных правах» ${ }^{6}$ и Закона Италии от 22 апреля 1941 г. «Об охране авторского права и других прав, связанных с его осуществлением» ${ }^{7}$, можно выдвинуть версию об объединении институтом смежных прав положений, относящихся к

\footnotetext{
${ }^{4}$ United Kingdom. Copyright, Designs and Patents Act, 1988. Available at: https://www.legislation.gov.uk/ ukpga/1988/48/contents. [Accessed $1^{\text {st }}$ July 2020].

${ }^{5}$ В частности, см.: United Kingdom. Dramatic and Musical Performers' Protection Act, 1925; Dramatic and Musical Performers' Protection Act, 1958. Available at: http://www.legislation.gov.uk/ukpga/1958/44/enacted [Accessed $4^{\text {th }}$ July 2020].

${ }^{6}$ Österreich. Bundesgesetz über das Urheberrecht an Werken der Literatur und der Kunst und über verwandte Schutzrechte. Available at: https://wipolex.wipo.int/en/legislation/details/18678 [Accessed 1 $1^{\text {st }}$ July 2020].

${ }^{7}$ Italia. Legge 22 aprile 1941 № 633 sulla protezione del diritto d'autore e di altri diritti connessi al suo esercizio. Available at: https://www.gazzettaufficiale.it/eli/id/1941/07/16/041U0633/sg [Accessed $5^{\text {th }}$ July 2020].
} 
результатам интеллектуальной деятельности, не удовлетворяющим условиям предоставления авторско-правовой охраны, в частности, критерию новизны и/или оригинальности, следующему из творческого характера деятельности автора. Особенно явно применение этого критерия прослеживается в отношении к фотографиям. Позицию, согласно которой ключевым критерием разграничения авторских и смежных прав является недостаточно творческий характер объектов $^{8}$, можно встретить и в российской правовой литературе (Korshunov \& Jeriashvili (eds.), 2017:13). То есть результаты интеллектуальной деятельности, отнесенные к объектам смежных прав, создаются в результате применения технических средств, и сама деятельность создателей таких результатов не относится к творческой, или критерий творчества в деятельности этих лиц не является решающим. При этом создаваемые результаты связаны с произведениями или по своей природе близки (или даже тождественны) им. Такой «объектный» подход свойственен законодательствам тех стран, которые были своего рода родоначальниками этого института.

В соответствии с подходом, в основе которого лежит «юридико-техническая идея» (Matveev, 2019 a:58), выделение норм о смежных правах в отдельную главу, раздел и т. д. и объединение их под общим названием является результатом законодательной техники. Если в отношении объектов авторского права предъявляются единые требования для предоставления охраны, устанавливается единый срок действия прав, общий набор правомочий и т. д., то есть образуется единый комплекс, то объекты смежных прав разнородные, правомочия им предоставляются в разном объеме, сами предоставляемые субъектам права по своей природе также отличаются и срок действия прав в отношении разных объектов не совпадает. Права исполнителей признаются за их личный вклад в создание исполнений (интерпретация ими произведений, как правило, носит творческий характер). Права изготовителей фонограмм, видеограмм (например, во Франции и Швейцарии), изготовителей баз данных, публикаторов посмертных изданий и организаций вещания признаются в отношении результатов, носящих организационно-технический характер. Как отмечает А.Г. Матвеев, «смежные права аккумулируют в себе разнохарактерные институты, которые объектно или функционально связаны с авторским правом, и что, скажем прямо, такая несистемная организация института смежных прав позволяет, в то же время, сохранить целостность и обособленность авторского права как института, направленного на охрану творческих произведений науки, литературы и искусства» (Matveev, 2019b:128).

Таким образом, выделяя положения о правах, смежных, родственных и т. д. с авторскими, законодатели пытаются сохранить целостность континентальной концепции авторского права, в которой охраняются, в первую очередь, интересы автора как творческой личности, что выражается в признании за ним личных неимущественных прав в отношении созданного им произведения, и лишь вторично его имущественные интересы, и как следствие признается за ним

\footnotetext{
${ }^{8}$ В оригинале указывается на нетворческий характер прав.
} 
исключительное право. В связи с этим некоторые специалисты сомневаются в существовании самостоятельного единого института смежных прав (Gavrilov, 2003:211).

Скептически относился к институту смежных прав и В.А. Дозорцев, который говорил о смежных правах в составе художественных прав, рассматривая их не как группу объектов, объединенных какими-то общими юридическими признаками, а как три совершенно самостоятельных объекта (Dozortsev, 2005:352). То есть, он видел в объединении смежных прав некую юридическую формальность, а не формирование целостного института.

Но предположение о том, что применение «юридико-технического» подхода - это единственное основание для формирования института смежных прав, представляется ущербным. Возможно, что применение такого подхода для предоставления правовой охраны любым объектам могло бы быть удобным для законодателя, поскольку отсутствует необходимость выявления общих закономерностей и характеристик. В этой связи при таком подходе при возникновении общественного запроса в правовой охране нематериального объекта и несоответствии его требованиям авторско-правовой охраны положения об охране любого такого объекта относились бы к институту смежных прав. Если придерживаться этого подхода, то топологии интегральных микросхем тоже следовало бы включить в раздел «смежные права». При этом в законодательных актах многих государств, например, Австрии ${ }^{9}$, Германии ${ }^{10}$, России, Швейцарии ${ }^{11}$, Японии ${ }^{12}$, топологии охраняются как самостоятельный результат интеллектуальной деятельности, в отношении которого предоставляется специальная правовая охрана (sui generis). Кроме того, в рамках Межправительственного комитета ВОИС по генетическим ресурсам, традиционным знаниям и фольклору ${ }^{13}$ на протяжении примерно 20 лет ведутся дискуссии о возможности охраны традиционных знаний ${ }^{14}$ и традиционных выражений культуры (выражений фольклора) ${ }^{15}$, однако оптимальное решение пока не найдено, а применение института смежных прав для охраны указанных объектов даже не обсуждается.

\footnotetext{
${ }^{9}$ Österreich. Bundesgesetz vom 23. Juni 1988 über den Schutz der Topographien von mikroelektronischen Halbleitererzeugnissen. Available at: https://wipolex.wipo.int/en/text/481686. [Accessed 10 October 2020].

${ }^{10}$ Deutschland. Gesetz über den Schutz der Topographien von mikroelektronischen Halbleitererzeugnissen. Available at: https://wipolex.wipo.int/en/text/461526. [Accessed 10 ${ }^{\text {th }}$ October 2020].

${ }^{11}$ Schweiz.Bundesgesetz vom 9. Oktober 1992 über den Schutz von Topographien von Halbleitererzeugnissen. Available at: https://wipolex.wipo.int/en/text/480404. [Accessed 10 ${ }^{\text {th }}$ October 2020].

12 Japan. Law on the Circuit Layout of a Semiconductor Integrated Circuits (Act № 43 of May 31, 1985). Available at: https://wipolex.wipo.int/en/text/187322 [Accessed $10^{\text {th }}$ October 2020].

13 Подробнее о деятельности Межправительственного комитета ВОИС по интеллектуальной собственности, генетическим ресурсам, традиционным знаниям и фольклору и документах, разрабатываемых в рамках данного комитета см.: https://www.wipo.int/tk/ru/igc/index.html (дата обращения: 10.10.2020).

${ }_{14}^{14}$ Например, см.: Охрана традиционных знаний: проект статей. Документ WIPO/GRTKF/IC/39/4 от 20.12.2018: https://www.wipo.int/edocs/mdocs/tk/ru/wipo_grtkf_ic_39/wipo_grtkf_ic_39_4.pdf (дата обращения: 06.10.2020).

${ }^{15}$ Например, см.: Охрана традиционных выражений культуры: проект статей. Документ WIPO/GRTKF/IC/39/5 от 20.12.2018: https://www.wipo.int/edocs/mdocs/tk/ru/wipo_grtkf_ic_39/ wipo_grtkf_ic_39_5.pdf (дата обращения: 10.10.2020).
} 
Следует обратить внимание на мнение Ф. Штольца, который указывал, что объединение смежных прав в Законе Германии от 9 сентября 1965 г. «Об авторском праве и смежных правах» ${ }^{16}$ в отдельную главу под общим названием «смежные права» было обусловлено не только учетом законодательной техники, но и стремлением законодателя обеспечить регулирование достойных правовой охраны результатов деятельности, связанных с использованием результатов творчества авторов. Попытка продемонстрировать имеющуюся связь между объектами (авторского права и смежных прав) показывается в обозначении, используемом в отношении прав на охрану результатов деятельности, «смежные права» (или как их иногда именуют «родственные права») (Stolz, 1986: 859-864). Таким образом, законодательная техника сама по себе не является первостепенным фактором выделения смежных прав, она только выполняет функцию вспомогательного инструмента.

Другой подход к формированию смежных прав основан на функциональном назначении результатов интеллектуальной деятельности субъектов смежных прав. Как отмечается в правовой литературе, изданной ВОИС, смежные права предоставляются лицам, содействующим создателям в распространении их произведений среди широкой общественности ${ }^{17}$. Авторам требуются посредники, профессиональные способности которых позволяют придать произведениям те формы изложения, которые позволяют сделать произведения доступными широкой публике ${ }^{18}$. Такая идея поддерживается как российскими, так и зарубежными специалистами. Месуми Огава, анализируя работы профессора К. Абэ, отмечает, что популяризация смежных прав особенно активизировалась по мере развития средств массовой информации наряду с развитием технологической цивилизации (Ogawa, 2006:174). Благодаря деятельности субъектов смежных прав те произведения авторов, которые были предназначены для публичного исполнения, становятся доступными более широкой общественности, чем зрители или слушатели, и тем самым оказывают положительное воздействие и на интересы самих авторов (Karanda, 2001:30), что соответственно является объединяющим таких субъектов фактором.

М.Н. Кузнецов, анализируя истоки появления смежных прав в зарубежном законодательстве, приходит к выводу о том, что экономическая ситуация создала у представителей бизнеса заинтересованность в предоставлении прав, аналогичных авторским правам, «тем лицам, которые доносят созданные автором произведения до публики» (Kuznetsov, 1986:48). О.С. Фролова, исследуя институт смежных прав, склоняется к функциональному подходу, заложенному при создании данного института (Frolova, 2007: 93-100). Как отмечает О.С. Фролова, деятельность исполнителей, изготовителей фонограмм и организаций вещания способствует тому, чтобы произведения становились доступными для широкого круга лиц (Frolova, 2007:93-100). На распространение авторских произведений и

\footnotetext{
${ }^{16}$ Deutschland. Gesetz über Urheberrecht und verwandte Schutzrechte. Available at: https://www.gesetze-iminternet.de/urhg/ [Accessed $4^{\text {th }}$ July 2020].

${ }^{17}$ WIPO Intellectual Property Handbook (2008) WIPO Publication No 489 (E). Geneva. Switzerland. P. 46.

${ }^{18}$ WIPO Intellectual Property Handbook (2008) WIPO Publication No 489 (E). Geneva. Switzerland. P. 46.
} 
обеспечение их сообщения для всеобщего сведения практически неограниченной аудитории указывают в том числе Д. Липцик (Lipszyc, 2002:304) и Р.Ш. Рахматулина (Korshunov \& Haritonova (eds.), 2017:170). Таким образом, смежными правами регулируются отношения, касающиеся в широком смысле культурнопосреднических результатов деятельности (Schack, 2001:29).

Однако А.Г. Матвеев прослеживает ущербность функционального подхода, который, по его мнению, проявляется в том, что такой поход «не объяснят охрану нетворческих баз данных, пресс-публикаций и недостаточно полно раскрывает охрану прав вещательных организаций» (Matveev, 2019 a:58).

Представляется, что в основе интеллектуальных прав, включая авторские, смежные, патентные и т. д., лежит баланс интересов создателей результатов интеллектуальной деятельности, обладателей прав такие результаты и на средства индивидуализации (правообладателей) и общества. В противном случае государство не имело бы заинтересованности вводить правовые институты и тратить ресурсы для защиты таких прав (в том числе с привлечением судебных и правоохранительных органов). У автора возникает интерес в раскрытии своего произведения общественности в обмен на предоставляемое право. Изготовитель базы данных осуществляет/организует трудоемкую или затратную работу по поиску и систематизации (обработке) информации. Предоставляя право изготовителю, государство исходит не только из того, что после прекращения срока действия исключительного права база данных перейдет в общественное достояние, но вводит систему ограничений и исключений из исключительного права, позволяющих использовать такой объект в научных, образовательных и иных, указанных в законе целях. Но главное, посредством базы данных создается источник информации, собирая и систематизируя информацию, изготовитель, в конечном итоге, способствует ее распространению среди общественности и тем самым способствует развитию науки и культуры. То же самое касается и пресс-публикаций.

Обладатели смежных прав дают возможность ознакомиться с произведениями и иными информационными объектами большему количеству заинтересованных представителей общественности. Их деятельность, как и деятельность авторов, способствует повышению информированности и культурному развитию общества. В этой связи представляется, что функциональный подход следует рассматривать как наиболее аргументированный.

Но не все специалисты поддерживают такой подход. Некоторые исследователи как основание для предоставления правовой охраны объектам смежных прав больше склоняются к идее «вклада» в создание объекта, направленного на доведение произведений до публики ${ }^{19}$, в том числе Б. Гугенхольц, с той лишь разницей, что он говорит о «технологическом инвестировании» в звукозаписи и вещание (Hugenholtz, 2019:1007). В качестве существенной проблемы такой идеи о защите инвестиций в технологии Б. Гугенхольц видит отсутствие минимальных критериев предоставления смежных прав в отношении указанных объектов (Hugenholtz, 2019: 1008). При таком подходе минимальными критериями для

\footnotetext{
${ }^{19}$ The recasting of copyright $\&$ related rights for the knowledge economy. Executive Summary of final report. (2006). Available at: https://papers.ssrn.com/sol3/papers.cfm?abstract_id $=2018238$ [Accessed $4^{\text {th }}$ July 2020].
} 
оценки инвестиций для предоставления охраны фактически будут выступать технические затраты на запись и вещание. Что же касается более поздних смежных прав, то скорее всего речь идет уже не о «технологических инвестициях», а об инвестициях в агрегацию контента (Hugenholtz, 2019:1010). На организационный и финансовый вклад издателей в выпуск публикаций для прессы указывается, в частности, в пункте 55 преамбулы Директивы (ЕС) 2019/790 Европейского Парламента и Совета от 17 апреля 2019 г. об авторском праве и смежных правах на едином цифровом рынке и поправках к директивам 96/9/EC и $2001 / 29 / \mathrm{EC}^{20}$.

Вместе с тем представляется, что предлагаемые исследователями подходы не являются абсолютно ошибочными. Институт смежных прав динамично развивающийся. Если провести анализ положений о смежных правах не в отдельно взятой стране, а в более глобальном масштабе, то можно предположить, что этот институт эволюционирует, и подходы, применяемые к этому институту, меняются. Обратившись к истокам формирования института смежных прав (примерами могут служить указанные выше законы Австрии и Италии), можно заметить, что в тот исторический период представители многих государств искали правовые возможности для охраны объектов, в полной мере не удовлетворяющих критериям авторско-правовой охраны. Это в определенной степени объясняет обширный перечень охраняемых смежными правами объектов в Австрии и Италии.

Следующим этапом развития института смежных прав является функциональный подход, при котором основное назначение объектов рассматривается как решающий критерий предоставления охраны. Не все объекты, которые не удовлетворяли критерию авторско-правовой охраны, подпадали под применение института смежных прав, а только те, которые способствовали ознакомлению общественности с произведениями и иными информационными объектами.

В настоящее время имеются предпосылки перехода на следующий этап эволюционного развития института смежных прав, при котором на первое место выходят организационные характеристики (предыдущие, указанные выше, два фактора сохраняются, но не рассматриваются как решающие). Например, Суд по интеллектуальным правам при признании за лицом (ООО «ВКонтакте») правового статуса изготовителя базы данных акцентировал внимание на создании изготовителем условий для наполнения базы данных с осуществлением последующей обработки, а на не самостоятельном заполнении базы данных и указал нижестоящим судам на необходимость оценки существенности затрат на создание базы данных ${ }^{21}$. В другом споре между общественными организациями «Мир тесен» и «Чемодан добрых дел» суду на основе представленных доказательств предстояло установить, является ли элемент социальной сети («группа») базой

\footnotetext{
${ }^{20}$ Directive (EU) 2019/790 of the European Parliament and of the Council of 17 April 2019 on copyright and related rights in the Digital Single Market and amending Directives 96/9/EC and 2001/29/EC. Official Journal of the European Union. L 130, 17.05.2019, pp. 92-125.

${ }^{21}$ Постановление Суда по интеллектуальным правам от 24 июля 2017 г. по делу № A40-18827/2017 // СПС «Консультант Плюс».
} 
данных, охраняемой смежным правом, или данный элемент был сгенерирован автоматически системой сайта ${ }^{22}$.

По той же причине в будущем могут возникнуть предпосылки для признания смежных прав за организаторами создания результатов (нематериальных объектов) при помощи высокотехнологичных решений, в том числе технологий искусственного интеллекта. Поскольку в целях поддержания правопорядка будет необходимо определить не только то лицо, которое будет получать преимущества материального и иного характера от использования результатов, созданных при помощи технологии искусственного интеллекта, но и нести ответственность за действия по неправомерному использованию, осуществленные такой технологией. Уже сейчас в процессе правоприменения возникают вопросы, следует ли рассматривать действия в отношении охраняемого объекта (в частности, извлечение или копирование данных, в том числе в большом объеме), которые осуществляет не человек, а технология, например, технология искусственного интеллекта, как использование результата интеллектуальной деятельности (например, базы данных), как это имело место при рассмотрении иска о защите исключительного права на базу данных «HeadHunter» ${ }^{23}$.

Развитие института смежных прав происходит в разных странах не одновременно. Ряд государств изначально поощряли организационную деятельность и предоставляли таким субъектам смежные права. Другие страны пока изучают возможность предоставления смежных прав за организационный вклад в создание результата интеллектуальной деятельности, например, как это происходит в отношении баз данных (в части охраны ее содержания от неправомерного копирования или извлечения ее существенной части). По этой же причине обсуждение вопроса о международной охране таких баз данных в рамках Постоянного комитета ВОИС по авторскому праву и смежным правам в настоящее время приостановлено.

Краткий анализ концептуальных подходов показывает, что касательно смежных прав в законодательстве однозначно определены субъекты, объекты, в отношении которых предоставляются смежные права, учитывается функциональное назначение таких объектов, а также экономический и организационный вклад субъектов, в отношении которых могут признаваться соответствующие права. Данную информацию следует учесть при рассмотрении понятия и основных характеристик смежных прав.

\section{Понятие и основные характеристики смежных прав}

В настоящей статье смежные права рассматриваются и как правовой институт, входящий в право интеллектуальной собственности (в объективном смысле), и как права, признаваемые в отношении результатов интеллектуальной деятельности за лицами, содействующими распространению произведений и

\footnotetext{
22 Решение Арбитражного суда г. Санкт-Петербурга и Ленинградской области от 31 августа 2015 г. Available at: http://kad.arbitr.ru/PdfDocument/9da17e68-9e4c-41b7-8865-aa738759387e/1ecb9753-4aa547ad-81d3-15ebc4114f1a/A56-58781-2012_20150831_Reshenie.pdf. [Accessed 10 ${ }^{\text {th }}$ October 2020].

${ }^{23}$ Решение Московского городского суда от 27 апреля 2018 г. по делу № 3-91/2018 // СПС «Консультант Плюс».
} 
иной информации (в субъективном смысле). Формирование в России института смежных прав связывают с Основами гражданского законодательства СССР и республик 1991 г., вступившими в силу в России в 1992 г., в которых нашли отражение положения о смежных правах, признаваемых за исполнителями, создателями звуко- и видеозаписей, организациями эфирного вещания (ст. 141-143). Понятие «смежные права» использовалось в названии ст. 141 в качестве обобщающего понятия, охватывающего права исполнителей, создателей звуко- и видеозаписей, организаций эфирного вещания. В Законе Российской Федерации от 9 июля 1993 г. № 5351-I «Об авторском праве и смежных правах» смежным правам был посвящен раздел III данного закона. В сменившей упомянутый закон части четвертой ГК РФ глава 71 именуется «Права, смежные с авторскими». Исходя из положений ст. 1303 ГК РФ понятия «права, смежные с авторскими» и «смежные права» рассматриваются как синонимы.

В п. 1 ст. 1303 ГК РФ указывается, что интеллектуальные права на результаты исполнительской деятельности (исполнения), на фонограммы, на сообщение в эфир или по кабелю радио- и телепередач (вещание организаций эфирного и кабельного вещания), на содержание баз данных, а также на произведения науки, литературы и искусства, впервые обнародованные после их перехода в общественное достояние, являются смежными с авторскими правами. Если в Основах гражданского законодательства 1991 г. акцент был смещен в сторону субъектов, и смежными правами объединялись права исполнителей, создателей звуко- и видеозаписей и организаций эфирного вещания, то ГК РФ категория «смежные права» объединяет права в отношении поименованных в п. 1 ст. 1303 ГК РФ объектов. Представляется, что положения п. 1 ст. 1303 ГК РФ не раскрывают сущности смежных прав, а только перечисляют объекты, охраняемые смежными правами.

Понятию и основным характеристикам смежных прав в юридической литературе уделяется внимание российскими специалистами в области права, в том числе в работах И.А. Близнеца и К.Б. Леонтьева (Bliznets \& Leont'ev, 2015), И.А. Зенина (Zenin, 2013; 2019), Э.П. Гаврилова (Gavrilov, 2003), В.Л. Энтина (Entin, 2018) и других. Одним из первых в советской юридической литературе понятие «смежные права» упомянул В.И. Серебровский. Рассуждая о правах артистов-исполнителей, он указал, что устанавливая охрану прав указанных субъектов, «правильней было бы говорить правах <смежных> или <родственных> с авторским правом» (Serebrovskiy, 1956:87).

Говоря о смежных правах как о правовом институте, И.А. Зенин отмечает, что «смежные права представляют собой совокупность норм гражданского права, регулирующих отношения по охране исполнений, постановок, фонограмм, передач организаций эфирного и кабельного вещания, установлению режима их использования, наделению исполнителей, производителей фонограмм и вещательных организаций личными неимущественными и имущественными правами и защите этих прав» (Suhanov (ed.), 2015:752). Тождественное определение можно найти и в работах других специалистов (Kost'kova, 2005). 
Е.С. Гринь, раскрывая понятие «смежные права» в объективном смысле, дает более широкое определение, говоря уже не только о нормах гражданского права, но и о совокупности «правовых норм, регулирующих общественные отношения, связанные с созданием и использованием объектов смежных прав, осуществлением данных прав и их защитой» (Novoselova (ed.), 2017:100). Несколько дискуссионным аспектом в данном определении представляется указание на регулирование отношений, связанных с созданием объектов смежных прав. Например, если говорить о сообщениях в эфир организаций вещания, то вопросы создания именно сообщений в большей степени относятся к получению лицензий на вещание, выполнению технических регламентов и иных норм публичного права. Возможно, предлагаемая Е.С. Гринь конструкция направлена на то, чтобы показать, что признание смежных прав в случае использования при создании соответствующих объектов смежных прав произведений или иных объектов смежных прав зависимо от правомерности использования указанных объектов, и создание таких объектов предваряет работа по урегулированию отношений, направленных на правомерное использование объектов авторского права и смежных прав для создания новых объектов смежных прав.

Помимо определений понятия «смежные права» в объективном смысле, некоторые специалисты предлагают формулировки термина «смежные права» в субъективном смысле, в понимании права (прав), признаваемого за лицом, которое наделается дополнительными правовыми привилегиями.

Например, В.А. Белов рассматривает смежные права как «исключительные права на оригинальные результаты творческой деятельности, соединенной с применением технических навыков» (Belov, 2012:470). В определении, представленном В.А. Беловым, основные акценты сделаны на категорию прав, к которой относятся смежные права, охраняемые результаты и указание на применение технических навыков. Следует отметить, что, во-первых, В.А.Белов исследует смежные права только с точки зрения российского права, так как в законодательных актах других стран, в частности европейских стран, применительно смежным правам говорят и об исключительном праве (правах), и о таком имущественном праве как право, на вознаграждение (без указания на то, что оно рассматривается как исключительное). Кроме того, даже применительно к Российской Федерации в соответствии с п. 2 ст. 1303 ГК РФ помимо исключительного права, к смежным правам в случаях, предусмотренных ГК РФ, относятся также личные неимущественные права.

Во-вторых, объекты смежных прав могут быть созданы и без использования произведений, охраняемых авторским правом, например, исполнение произведений, перешедших в общественное достояние, произведений народного творчества, автор которых не известен, сообщение в эфир или по кабелю новостей, фонограмма звуков природы. Справедлива и критика данного определения Э.П. Гавриловым, который указывает на то, что результатом творческой деятельности среди объектов смежных прав рассматривается только исполнение. При этом некоторые субъекты смежных прав, например, исполнители 
и публикаторы, технические навыки при создании результатов не используют (Gavrilov, 2015:271).

В зарубежных источниках можно встретить определение, согласно которому смежные права - это права, связанные с авторским правом, которые гарантируют, что определенные категории физических лиц или организаций, вносящих вклад в культурный акт, могут получать доход от своей деятельности ${ }^{24}$. В представленном определении акцент смещен с характеристик смежного права в сторону основания предоставления такого права, подчеркивая внесение вклада в осуществление некоего культурного процесса.

Для того чтобы дать определение смежным правам, представляется целесообразным рассмотреть основные характеристики смежных прав, выделив среди них те, которые относятся именно к данной категории.

Смежные права, как и иные права, относящиеся к категории интеллектуальных прав, признаются в отношении объектов, носящих нематериальный характер. Смежные права не следуют за вещью, в которой выражен нематериальный объект, в отношении которого признается соответствующее право. Их наличие не зависит от права собственности на вещь, в которой может быть зафиксирован результат интеллектуальной деятельности, относящийся к объектам смежных прав. Прекращение права собственности на такую вещь (материальный носитель записи) также не влечет прекращения смежного права. Проблемы реализации исключительного права и его защиты возможны в случае, если исполнение не было записано во время исполнения или было записано, но единственный материальный носитель утерян, поврежден и т. д.

Законодательно установлен принцип исчерпания исключительного права в случае правомерного введение оригинала или экземпляра фонограммы в гражданский оборот на территории Российской Федерации путем их продажи или иного отчуждения (ст. 1325 ГК РФ). Исключительное право не может быть далее реализовано в отношении распространения конкретного оригинала или экземпляра фонограммы, но не иных правомочий правообладателями фонограммы как охраняемого результата интеллектуальной деятельности.

Смежные права применительно к исключительным правам в Российской Федерации оборотоспособны и могут предоставляться и отчуждаться в полном объеме. В некоторых странах смежные права могут предоставляться как право использования третьим лицам, но не могут отчуждаться в полном объеме, или предоставление права использования может касаться отдельного(-ых) правомочия(-й) (способа использования) (например, в Германии).

В законодательных актах некоторых стран предусмотрена презумпция передачи или предоставления прав, связанных с отдельными способами использования исполнений в отношении записи на фонограмму или в связи с созданием аудиовизуального произведения (в частности, п. 4 ст. 1317 ГК РФ, ст. L. 212-4

\footnotetext{
${ }^{24}$ The emergence of Community-wide protection for creativity. Copyright and neighbouring rights in the European Community. 9/1991. Available at: https://op.europa.eu/en/publication-detail/-/publication/ 85c9f31e-ec61-4aaa-a809-adb9ce2c4455/language-en/format-PDFA1B [Accessed 5 ${ }^{\text {th }}$ July 2020].
} 
Кодекса интеллектуальной собственности Франции ${ }^{25}$ ), в которое включается соответствующее исполнение.

Смежные права, как и иные исключительные права, относятся к абсолютным правам, и их следует рассматривать как некую монополию на использование объекта смежных прав. Иные лица обязаны воздержаться от использования определенного объекта, за исключением случаев, установленных законом, в частности, в России ГК РФ. В то же время, вступая в договорные правоотношения, например, заключая лицензионный договор, договор залога и т. д., исключительное смежное право в рамках этих отношений меняет свой характер. Оно становится предметом обязательственных (договорных) отношений. И для защиты нарушенного исключительного смежного права применяются способы, определенные ГК РФ, в том числе положения ст. 1252 ГК РФ. Однако эти положения неприменимы, если нарушение следует из исполнения обязательств по договору, за исключением случаев выхода сторон договора за его пределы (например, изготовление тиража фонограмм количеством большим, чем это предусмотрено договором и последующее распространение таких экземпляров без разрешения правообладателя).

Поскольку смежные права относят к интеллектуальным правам, им свойственны все те характеристики, которые могут считаться универсальными для прав, относящихся к этой категории.

Во-первых, результаты интеллектуальной деятельности, в отношении которых признаются смежные права, определены законодательными актами, и, перечень объектов смежных прав носит закрытый характер. Однако перечень охраняемых результатов в государствах отличается. В качестве объектов смежных прав рассматриваются критические и научные издания произведений, которые не охраняются авторским правом (в частности, в Германии), фотографии и объекты, изготовленные способами, аналогичными фотографии, которые не являются охраняемыми произведениями, поскольку в создание таких объектов не был вложен личный творческий вклад автора (например, в Австрии, Германии, Дании, Италии), исполнения исполнителей, устроение исполнений, осуществленное организацией (например, концертной организацией) (в Германии), фонограммы, передачи организаций вещания (в России - сообщения в эфир или по кабелю), базы данных, являющиеся результатами существенной инвестиционной деятельности (в том числе в России, Германии, Дании, Норвегии), личная корреспонденция (в Австрии, Италии), инженерные проекты и портреты (в Италии), каталоги (в частности, в Дании, Финляндии), таблицы (например, в Дании), видеограммы (в частности, в Финляндии, Франции, Хорватии, Швейцарии), пресс-релизы (например, в Дании, Финляндии).

Во-вторых, смежные права, как и иные права, относящиеся к категории интеллектуальных прав, признаются в отношении объектов, носящих нематериальный характер. Данные права признаются за субъектами, осуществляющими

\footnotetext{
${ }^{25}$ France. Code de la propriété intellectuelle (version consolidée au 15 novembre 2019). Available at: https://wipolex.wipo.int/en/text/540561 [Accessed 10 ${ }^{\text {th }}$ October 2020].
} 
деятельность, результат которой обладает некой нематериальной самостоятельной формой, отличной от той, в которой существует авторское произведение, используемое для создания объекта смежных прав. Субъекты смежных прав, как и авторы произведений, сохраняют связь с созданными ими результатами интеллектуальной деятельности.

В-третьих, смежные права ограничены по территории, сроку действия, содержанию. То есть права на объекты смежных прав признаются только в той стране, либо где создан соответствующий объект, либо где он зафиксирован (для исполнений), либо гражданином (юридическим лицом) которой является субъект смежных прав, либо где опубликован или обнародован объект (для фонограмм), либо на территории страны, где организация имеет место нахождения или где расположены передатчики, с помощью которых осуществляется сообщение (для вещательных организаций). В других странах, кроме обозначенных выше случаев, объект смежных прав может охраняться только в соответствии с международным договором либо на основании принципа взаимности (например, в отношении баз данных).

Срок действия смежных прав зафиксирован в законе, он не может быть продлен или изменен по желанию правообладателя. Процедура досрочного прекращения смежных прав или отказа от них законодательством не предусмотрена. Объем предоставляемых смежным правом правомочий зависит от объекта смежных прав и в каждой конкретной стране может отличаться. Даже в тех случаях, когда правомочия правообладателей определены международным договором, такой объем охраны является минимальным, и это не препятствует государству признавать за правообладателями права в большем объеме.

А.Г. Матвеев, как и некоторые другие исследователи, отмечает, что исходя из международных договоров и актов Европейского Союза, смежные права являются исключительными (Matveev, 2019 a:56). Такое утверждение не в полной мере отражает существующее положение.

Во-первых, хотя права исполнителей, изготовителей фонограмм и вещательных организаций закреплены в специальном международном договоре Римской конвенции, непосредственно понятие «смежные права» не нашло отражение в указанном международном акте, и конвенция, соответственно, не относит предусмотренные права к смежным. Также как не упоминается данный термин в ряде заключенных после 1961 г. международных договорах, в том числе Конвенции об охране интересов производителей фонограмм от незаконного воспроизводства их фонограмм (Женева, 29 октября 1971 г.), Конвенции о распространении несущих программы сигналов, передаваемых через спутники (Брюссель, 21 мая 1974 г.), Договоре ВОИС по исполнениям и фонограммам (Женева, 20 декабря 1996 г., далее - ДИФ), Пекинском договоре по аудиовизуальным исполнениям (Пекин, 24 июня 2012 г., далее - Пекинский договор), посвященных отдельным видам результатов интеллектуальной деятельности, которые принято относить к объектам смежных прав. Понятие «смежные права» упоминается в Соглашении о торговых аспектах прав интеллектуальной собственности (ВТО, Уругвайский раунд многосторонних торговых переговоров, Марракеш, 15 апреля 1994 г., далее - Соглашение ТРИПС) и ряде 
международных договоров, носящих региональный характер, но в них не дается определение и не раскрывается сущность этих прав.

Во-вторых, что касается природы прав, относящихся к смежным, то помимо исключительного права, международные договоры предусматривают личные неимущественные права для исполнителей (например, ст. 5 ДИФ, ст. 5 Пекинского договора) и право на вознаграждение (в частности, ст.12 Римской конвенции, ст. 15 ДИФ). Следует учесть, что если в соответствии с ГК РФ право на вознаграждение рассматривается как составная часть исключительного права, в том числе при взимании вознаграждения (платы) с оборудования и чистых носителей за свободное воспроизведение фонограмм и аудиовизуальных произведений в личных целях, то в международных договорах и европейских актах право на вознаграждение рассматривается как самостоятельное имущественное право. Кроме того, в международных актах имеет место и «ограниченное» право - право запрещать неправомерное использование (например, ст. 7 Римской конвенции, Соглашение ТРИПС), предоставляющее государствам возможность устанавливать на национальном уровне различные меры правовой защиты, включая и публично-правовые. Применение подхода, когда смежное право как единое право субъекта рассматривается как состоящее из компонентов, например, смежное право исполнителя, состоящее из личных неимущественных прав, исключительного права и т. д., возможно только в рамках национальных исследований, но такой подход не будет приемлем в глобальном масштабе.

При этом, действительно, смежные права в основном носят имущественный характер (исключение составляют личные неимущественные права исполнителей (государствах континентального права) или так называемые моральные права (например, в Соединенном Королевстве), и наибольшее экономическое значение имеют исключительные смежные права.

Вместе с тем имеются характеристики, которые применимы, в основном, к смежным правам:

- деятельность субъектов смежных прав носит, как правило, организационно-технический и экономический характер. Смежными правами охраняется не личный, творческий вклад (к исключениям можно отнести исполнения) в создание результата интеллектуальной деятельности, а вклад, носящий организационно-технический и экономический характер. В этой связи от создателя результата интеллектуальной деятельности, относящегося к объектам смежных прав, не требуется проявления творчества и достижения оригинальности результата;

- целью предоставления смежных прав является поощрение деятельности, связанной с сообщением публике или предоставлением доступа к произведениям или информационным объектам. Предоставляемая охрана направлена, в конечном счете, на удовлетворение культурных, научных и образовательных потребностей общественности.

Таким образом, если говорить о смежных правах как о правовом институте (в объективном смысле), то они представляют собой систему правовых норм, регулирующих имущественные и связанные с ними личные неимущественные отношения в связи с использованием результатов интеллектуальной 
деятельности творческой организационно-технической или инвестиционной направленности, целью которой является сообщение общественности или предоставления ей доступа к произведениям или иным информационным объектам.

В субъективном смысле смежное право является признанной государством за лицом, создавшим результат интеллектуальной деятельности, направленный на сообщение общественности или предоставления ей доступа к произведениям или иным информационным объектам, либо осуществившим контроль и несущим ответственность за его создание, исключительной возможностью использовать такой результат по своему усмотрению или удовлетворять за его счет иные имущественные и/или личные неимущественные интересы способами, определенными законодательством.

\section{Заключение}

Анализ законодательных актов в сфере авторского права и смежных прав свидетельствует об эволюционном развитии института смежных прав, который изначально аккумулировал положения о правах на результаты интеллектуальной деятельности в сфере культуры, не в полной мере удовлетворяющие критериям, характерным для авторского права. Развитие, как и зарождение института смежных прав, связывают с совершенствованием технологий, позволяющих доводить произведения и иные информационные материалы для представителей публики. На современном этапе институт смежных прав расширяется в связи с экономической и социальной потребностью поощрения деятельности лиц, вносящих организационный, финансовый или иной вклад в сбор, обработку и распространение произведений и информации, и интенсификацией применения информационно-телекоммуникационных сетей, которые создают дополнительные предпосылки активного использования результатов интеллектуальной деятельности без учета интересов лиц, создавших такие результаты или инициировавших их создание и несущих ответственность за их правомерное использование. Имеются основания предполагать, что признание смежных прав за издателями прессы и информационными агентствами в Европейском Союзе не является завершающим звеном совершенствования института смежных прав, и в будущем возможно появление новых смежных прав в отношении субъектов, содействующих повышению информированности и культурному развитию общества.

$\mathrm{C}$ появлением цифровой среды и информационно-телекоммуникационных сетей, в частности, расширяются возможности представления творческих произведений представителям общественности. Виртуальная и дополненная реальности начинают стирать грани между исполнением и иными видами использования результатов интеллектуальной деятельности и созданием новых объектов. Например, погружаясь в мир иммерсивных объектов, пассивный зритель меняет свою роль на активного исполнителя. Либо наоборот, записав фрагмент звучания голоса исполнителя, вокалоид синтезирует данный голос применительно к исполнению различных произведений без участия человека, голос которого взят за основу. В связи с этим возникают вопросы, являются ли действия 
активного зрителя в иммерсивных представлениях или пение вокалоида исполнениями, и целесообразно ли предоставление охраны таким исполнениям. Правоприменительная практика в России по вопросам использования объектов смежных прав в цифровой среде до настоящего времени еще находится на стадии формирования. Представляется, что основные характеристики смежных прав и объектов таких прав, концептуальные подходы в признании за определенными лицами смежных прав могли бы содействовать выработке правовой позиции, в том числе при разрешении споров, связанных с использованием в цифровой среде результатов интеллектуальной деятельности.

\section{References / Список литературы}

Belov, V.A. (2012) Civil law. Common part. Introduction to civil law. 2nd ed. Moscow, Yurayt Publ. (in Russian).

Белов В.А. Гражданское право. Т. 1. Общая часть. Введение в гражданское право: учебник. 2-е изд. перераб. и доп. М.: Юрайт, 2012. 512 с.

Bliznets, I.A. \& Leont'ev, K.B. (2015) Copyright and related rights. 2nd ed. Moscow, Prospekt Publ. (in Russian).

Близнеи И.А., Леонтьев К.Б. Авторское право и смежные права. 2-е изд. М.: Проспект, 2015. $452 \mathrm{c}$.

Dozortsev, V.A. (2005) Intellectual rights. Concept. System. Codification tasks. Moscow, Statut Publ. (in Russian).

Дозориев B.A. Интеллектуальные права. Понятие. Система. Задачи кодификации. Сборник статей. М.: Статут, 2005. 416 с.

Dworkin, G. \& Taylor, R.D. (1989) Blackstone's Guide to the copyright, designs and patents act 1988. London, Blackstone Press.

Ficsor, M. (ed.) (2004) Guide to the copyright and related rights treaties administered by WIPO and glossary of copyright and related rights terms. WIPO Publication No. 891(E), Geneva, Switzerland.

Frolova, O. (2007) Concept and legal nature of subjective related rights. Business and Law Journal. (7), 93-100. (in Russian).

Фролова О. Понятие и правовая природа субъективных смежных прав // Хозяйство и право. 2007. № 7. С. 93-100.

Gavrilov, E.P. (2003) Commentary on the Law on Copyright and Related Rights. Moscow, Ekzamen Publ. (in Russian).

Гаврилов Э.П. Комментарий к Закону об авторском праве и смежных правах. М.: Экзамен, 2003. 352 с.

Gavrilov, E.P. (2015) Intellectual Property Law. General provisions. XXI century. Moscow, Yurservitum Publ. (in Russian).

Гаврилов Э.П. Право интеллектуальной собственности. Общие положения. XXI век. М.: Юрсервитум, 2015. 492 с.

Hugenholtz, B.P. (2019) Neighbouring Rights are Obsolete. IIC. International Review of Intellectual Property and Competition Law. 50 (8), October. 1006-1011.

Entin, V.L. (2018) Intellectual property in European Union law. Moscow, Statut Publ. (in Russian). Энтин В.Л. Интеллектуальная собственность в праве Европейского Союза. М.: Статут, 2018. $173 \mathrm{c}$.

Karanda, M. (2001) Functional features of the institute of related rights. Intellectual property. Copyright and related rights. (2), 30-41. (in Russian). 
Каранда М. Функциональные особенности института смежных прав // Интеллектуальная собственность. Авторское право и смежные права. 2001. № 2. С. 30-41.

Korshunov, N.M. \& Jeriashvili, N.D. (eds.) (2017) Intellectual property right. 2nd ed. Moscow, JUNITI-DANA: Zakon i pravo Publ. (in Russian).

Право интеллектуальной собственности: учебное пособие. Под ред. Н.М. Коршунова, Н.Д. Эриашвили, 2-е изд. перераб. и доп. М.: ЮНИТИ-ДАНА: Закон и право, 2017. $271 \mathrm{c}$.

Korshunov, N.M. \& Haritonova, Ju.S. (eds.) (2017) Intellectual property (Rights to the results of intellectual activity and means of individualization). Moscow, Norma: INFRA M Publ. (in Russian).

Интеллектуальная собственность (Права на результаты интеллектуальной деятельности и средства индивидуализации): учебное пособие / под общ. ред. Н.М. Коршунова, Ю.С. Харитоновой. 2-е изд., перераб. М.: Норма: ИНФРА М, 2017. 384 с.

Kost'kova, O.V. (2005) Article-by-article commentary to the Federal Law "On Copyright and Related Rights". Moscow, Novaya pravovaya kul'tura Publ. (in Russian).

Костькова O.В. Постатейный комментарий к ФЗ «Об авторском праве и смежных правах». М.: Новая правовая культура, 2005 // Справочно-правовая система «Гарант».

Kuznetsov, M.N. (1986) Protection of Copyright in Private International Law. Moscow, UDN Publ. (in Russian).

Кузнецов М.Н. Охрана авторских прав в международном частном праве: Учебное пособие. М.: Изд-во УДН, 1986. 107 с.

Lipszyc, D. (2002) Copyright Law and Neighboring Rights. Moscow, Ladomir Publ. (In Russian). Липиик Д. Авторское право и смежные права. М.: Ладомир, 2002. 788 с.

Matveev, A.G. (2019 a) The idea of related rights and their varieties. Journal of the Intellectual Property Court. (24), 54-60. (in Russian).

Матвеев А.Г. Идея смежных прав и их разновидности // Журнал суда по интеллектуальным правам. 2019. № 24. С. 54-60.

Matveev, A.G. (2019 b) Continental and Anglo-American traditions of protection of related rights: general and different. Humanities, socio-economic and social sciences. (8), 126-129. (in Russian).

Матвеев А.Г. Континентальная и англо-американская традиции охраны смежных прав: общее и различное // Гуманитарные, социально-экономические и общественные науки. 2019. № 8. С. 126-129.

Novoselova, L.A. (ed.) (2017) Intellectual Property Rights. T. 2. Copyright. Textbook. Moscow, Statut Publ. (in Russian).

Право интеллектуальной собственности. Т. 2. Авторское право: учебник / Под общ. ред. Л.А. Новоселовой. М.: Статут, 2017. 367 с.

Ogawa, M. (2006) Protection of Broadcasters' Rights. Leiden/Boston. Martinus Nijhoff Publishers. The Netherlands.

Schack, H. (2001) Urheber- und Urhebervertragsrecht. 2. Aufl., Tubingen. Mohr Siebeck. Deutschland. (in German).

Serebrovskiy, V.I. (1956) Issues of Soviet Copyright Law. Moscow, AN SSSR Publ. (in Russian). Серебровский. В. Е. Вопросы советского авторского права. М.: АН СССР, 1956. 283 с.

Stolz, F. (1986) Die Rechte der Sendeunternehmen nach Inkrafttretten der Urheberrechtsnovelle von 1985. GRUR. (12), 859-864. (in German).

Suhanov, E.A. (ed.) (2015) Russian civil law: General part. Property law. Inheritance law. Intellectual rights. Personal non-property rights. $4^{\text {th }}$ ed. Moscow, Statut Publ. (in Russian). Российское гражданское право: учебник: в 2 т. Т. I: Общая часть. Вещное право. Наследственное право. Интеллектуальные права. Личные неимущественные права / Отв. ред. Е.А. Суханов. 4-е изд., стер. М.: Статут, 2015. 958 с. 
Zenin, I.A. (2019) Intellectual property law. 10 ${ }^{\text {th }}$ ed. Moscow, Yurayt Publ. (in Russian). Зенин И.А. Право интеллектуальной собственности: учебник: в 2 ч. Ч. 1. 10-е изд., перераб. и доп. М.: Издательство Юрайт, 2019. 318 с.

Zenin, I.A. (2013) Origin and development of the Institute of related rights in the Russian Federation. Intellectual property law. (1). 3-11. (in Russian).

Зенин И.А. Зарождение и развитие института смежных прав в Российской Федерации // Право интеллектуальной собственности. 2013. № 1. С. 3-11.

\section{Об авторе:}

Бузова Наталья Владимировна - кандидат юридических наук, ведущий научный сотрудник Центра исследования проблем правосудия, Российский государственный университет правосудия; 117418, Российская Федерация, г. Москва, ул. Новочеремушкинская, д. 69 e-mail:nbuzova@yandex.ru

\section{About the author:}

Natalia V. Buzova - Candidate of Legal Sciences, Leading Researcher, Center for the Study of Justice Problems, Russian State University of Justice; 69 Novocheremushkinskaya str., Moscow, 117418, Russian Federation e-mail:nbuzova@yandex.ru 